\title{
A democracia, face política da globalização?
}

Is Democracy the Political Face of Globalization?

FERNANDO DE SOUSA

Rev. Bras. Polít. Int. 49 (1): 5-24 [2006]

\section{Introdução}

O mundo pós-Guerra Fria, ou melhor, o mundo após a extinção do bloco soviético (1989-1991), ultrapassada a velha rivalidade bipolar e a lógica política, económica e social que lhe estava subjacente, celebrou uma nova era baseada nos princípios do desenvolvimento e cooperação, enquanto fundamento de uma nova ordem mundial. Parecia estar aberto o caminho para a difusão dos valores e ideais democráticos, acelerada pelos progressos tecnológicos da informação, tanto mais facilitada quando, afundado o socialismo de Estado, parecia não existir qualquer outro modelo alternativo para a humanidade. Contudo, não tardou que este optimismo, inspirado na recuperação do idealismo característico das épocas pós-conflituosas, desse lugar a um conjunto de realidades bem mais duras, marcadas por tensões, violações de regras e direitos fundamentais, pelo eclodir de conflitos violentos, vincadamente étniconacionalistas, em grande parte de natureza supra-estatal, e ainda, pelo recrudescimento dos movimentos e acçóes terroristas, desvanecendo-se, assim, o sonho de uma nova ordem pautada pelos princípios da democracia, da paz e da cooperação.

Os desafios à construção democrática após o final da Guerra Fria e num período de crescente globalização são inúmeros. Atravessando fronteiras, cruzando ideologias e ultrapassando particularismos, a democratização contém amplas potencialidades, mesmo defrontando-se com inúmeras limitações. Diz respeito a uma multiplicidade de aspectos, incluindo, verticalmente, os vários níveis de organização social e política, desde as autoridades nacionais, locais e regionais até à sociedade civil, e horizontalmente abrangendo aspectos políticoideológicos, económicos, sociais e culturais. É da interligação destas duas dimensões, e da forma como estes factores se conjugam na formação da vida

\footnotetext{
* Professor catedrático da Universidade Lusíada do Porto, Portugal (fernandosousa@por.ulusiada.pt)
} 
em comunidade, que podemos entender a complexidade dos desafios da democratização no mundo pós-Guerra Fria.

Partindo da análise do conceito de "democracia", tantas vezes suscitando interpretações distorcidas e aplicações inadequadas, e do conceito de "globalização", cuja definição está longe de suscitar consensos, propomo-nos a analisar os desafios da democratização no mundo pós-Guerra Fria, num contexto de crescente globalização, olhando as profundas alteraçōes no cenário mundial resultantes do fim do sistema bipolar e da afirmação de um mundo cada vez mais permeável às mutações no sistema internacional, questionando processos e sugerindo alternativas.

\section{Uma leitura histórica do conceito de democracia}

Ao longo da história, os desafios da democratização têm caminhado par a par com as diferentes interpretações e valorações conferidas ao próprio entendimento de democracia. Literalmente significando "o governo (kracia) do povo (demos)", assumiu, em diferentes momentos e contextos, significados tão díspares que, em circunstâncias próprias, parece mesmo ilustrar realidades contrárias à sua simples formulação original.

Surgiu nas cidades-Estado da Grécia antiga, como um modelo de governação, onde todas as decisões fundamentais à vida em comunidade eram tomadas em assembleia popular, reunindo todos os cidadãos, que participavam, deste modo, na vida política da polis. Contudo, apenas uma percentagem diminuta da população tinha o estatuto de cidadão, uma vez que os escravos, que constituíam a maioria da população, as mulheres e os estrangeiros não gozavam de direitos políticos. Uma forma directa mas restritiva de participação popular, que, logo na sua génese, apesar de todas as virtudes, surgiu quase como antítese do ideal democrático.

Será, no entanto, já nos séculos XVII e XVIII, que o modelo democrático veio a conhecer desenvolvimentos determinantes. Partindo de uma reacção aos abusos de poder num contexto político caracterizado por governos autoritários, assentou nos princípios individualistas centrais ao liberalismo europeu, defendendo a existência de direitos naturais indissociáveis da própria existência humana, e que se sobrepõem aos desígnios de qualquer autoridade ou poder instituído. Com raiz nas ideias progressistas desenvolvidas por John Locke, Jean Jacques Rousseau e Montesquieu, entre muitos outros, a mudança consubstanciou-se nas Revoluçōes Inglesa (1688-1689), Americana (1776) e Francesa (1789). Como reaç̧ão ao período conturbado e de transformação profunda então vivido, na viragem do século XVIII para o século XIX, Alexis de Tocqueville irá definir a democracia como a conjugação de liberdade e igualdade, exigindo limites à actuação do Estado e maior participação dos cidadãos no exercício do poder político. 
Aliado aos avanços tecnológicos da Revolução Industrial iniciada na Inglaterra, em finais de Setecentos, os ideais políticos ligados aos princípios democráticos entraram numa fase de clara afirmação. Devido às dificuldades sociais emergentes na Europa industrializada do século XIX, as ideias socialistas vão ganhar forma e voz. Partindo do princípio da igualdade social, irão impulsionar um novo entendimento de democracia, imbuída, não apenas pelos princípios liberais e burgueses, como até então, mas plasmada numa versão marxista e proletária - que estará na base do desenvolvimento das democracias populares na Europa após a Segunda Guerra Mundial, à luz do modelo soviético implantado sobre a velha Rússia czarista, em 1917.

Neste contexto, registe-se a célebre máxima do presidente norte-americano, Abraham Lincoln, em Gettysburg, em 1864, num cenário de guerra civil, defendendo o "governo do povo, pelo povo e para o povo", a partir da qual as propostas de conceptualização de democracia assumiram tantas formas que, por vezes, o conceito parece perder significado.

Enquanto que na forma tradicional de democracia liberal, que nos é mais familiar, se valoriza o "governo do povo", pela procura do equilíbrio entre o princípio de limitação governativa e do consentimento popular, procurando, com base na condução de processos eleitorais competitivos e regulares, e num princípio de igualdade política, garantir liberdade e protecção aos cidadãos contra um poder opressivo, na forma mais radical de democracia totalitária, a valorização centra-se no princípio do "governo para o povo". Este último tipo de democracia assenta no entendimento de que só um líder carismático e ditador absoluto pode consubstanciar e articular os verdadeiros interesses do povo. Deste modo, apesar das democracias totalitárias, na sua génese, constituírem um desvio claro à noção convencional de governo democrático, a sua existência demonstra a tensão entre "governo do povo" ou "governo pelo povo", que promove a participação popular, seja de forma directa ou indirecta, e de "governo para o povo", que se diz sempre no interesse da população, e que sustentou os regimes fascistas e comunistas do século XX.

A amplitude do conceito é também revelada nas diferentes visões que suscita, enquadrando-se no debate contemporâneo quanto à forma mais desejável de democracia. Este envolve questões relativas aos benefícios reais da democracia, ao facto de ela assegurar efectivamente uma dispersão genuína e saudável do poder político, e às interrogações relativas à possibilidade de coexistência efectiva entre igualdade política e desigualdade económica. Questôes que sugerem diferentes perspectivas na procura de respostas e explicações para os desafios da democratização.

A uma perspectiva pluralista assente numa multiplicidade de interesses e grupos na sociedade capazes de articularem as suas visões de forma livre, com vista a garantir resposta popular e responsabilidade pública no sistema democrático liberal, opõe-se a visão elitista que acentua a tendência para o poder se concentrar 
nas mãos de uma minoria privilegiada - a elite - capaz de controlar e manipular as massas. Uma reacção à sociedade sem classes, com igualdade política, defendida pelos marxistas, preocupados com a tensão existente entre democracia e capitalismo, revelada na contradição do princípio de igualdade política proclamado pela democracia liberal, e na desigualdade económica resultante do capitalismo. A complementar estas perspectivas, o corporativismo enfatiza o papel dos organismos não governamentais na intermediação entre o público e o Estado, considerando o facto de existirem interesses organizados na sociedade, com acesso privilegiado à formulação de políticas sectoriais.

A acentuação de determinados aspectos nestas diferentes perspectivas demonstra as dificuldades em encontrar uma definição consensual, ao mesmo tempo que revela as fragilidades associadas à própria operacionalização do conceito, assumido, por exemplo, na possível estagnação política, em resultado do eventual aumento de poder de grupos de interesse e económicos decorrentes da concepção pluralista, ou do facto do público poder revelar desinteresse num sistema democrático elitista, onde a efectiva participação popular se pode resumir à escolha eleitoral.

Ao presente, a democracia, para além dos clássicos valores da igualdade e liberdade, está ligada também às questōes da segurança e direitos humanos, enquanto princípios e bases fundamentais das sociedades contemporâneas. Contudo, os diferentes modelos de democratização, como por exemplo o modelo ocidental em contraposição ao islâmico, têm revelado as diferentes vias existentes, tal como a formulação ambígua de certas expressões - "democracia controlada" ou "democracia incompleta" - a traduzir as dificuldades de operacionalização do conceito e a revelar a complexidade da realização e consolidação democráticas, e mais ainda, da sua avaliação.

Não existe, pois, um conceito unificado e completo de democracia, do mesmo modo que o modelo democrático não deve ser entendido como um modelo perfeito e acabado. As diferentes conceptualizações do termo e as disparidades encontradas na sua materialização prática são resultado dos desenvolvimentos político-sociais e económicos decorrentes da história e das conjunturas nacional e global, uma vez que o próprio curso do tempo moldou os regimes democráticos existentes, na procura de novas soluções e alternativas para os inúmeros desafios e constantes mutações do sistema internacional.

A forma como a democracia funciona na prática é, então, diversa, resultando num conceito abraçado por diferentes regimes políticos, sujeito a interpretaçôes distintas e com alcance variável. Contudo, o modelo mais próximo da génese do conceito refere-se ao "governo do povo". Assim, entendemos "democracia como uma forma de Governo assente no consentimento popular, permitindo aos cidadãos participar nas decisões políticas ou eleger representantes nos órgãos governamentais". Num regime democrático, o poder encontra-se limitado, a alternância governativa está eleitoralmente assegurada, 
os governados mantêm todos os seus direitos cívicos perante os governantes, a liberdade é respeitada e a competitividade política está sempre presente. Será a partir deste entendimento do conceito - designado correntemente como democracia liberal - que analisaremos os principais desafios da democratização no mundo pós-Guerra Fria.

\section{Uma análise crítica do conceito de globalização}

O conceito de globalização, de origem anglo-saxónica, forjado nas escolas de gestão americanas e sinónimo, em França, de mundialização, serviu para traduzir o extraordinário desenvolvimento das relações económicas em nível mundial, a partir dos anos 80 - inicialmente, a palavra teve apenas uma feição económica, designando, na expressão de Levitt, "a convergência de mercados do mundo inteiro", "um movimento complexo de abertura de fronteiras económicas e de desregulamentação, que permitiu às actividades económicas capitalistas estender o seu campo de acção ao conjunto do planeta".

O desmoronamento do bloco soviético e o aparente triunfo planetário do modelo liberal no início dos anos 90, acompanhados do desenvolvimento das novas tecnologias de comunicação e informação, deram a esta noção uma validade histórica. A globalização constituiu, assim, uma nova etapa na evolução do capitalismo industrial, sucedendo à internacionalização das firmas e capitais.

Sob o ponto de vista económico, a noção de globalização integra três fenómenos diferentes: o primeiro é o do desenvolvimento rápido dos mercados financeiros mundiais a partir dos finais dos anos 70, estimulados pela desregulamentação dos mercados financeiros e pelo aparecimento de novas tecnologias de informação; o segundo fenómeno é o da mundialização das actividades das empresas, tanto do sector manufactureiro como dos serviços; e o terceiro, de natureza ecológica, traduzindo uma inquietude geral que se desenvolveu a partir dos finais dos anos 80 . Estes três fenómenos estão na origem do sentimento de que os poderes públicos não podem controlar o funcionamento da economia e dos mercados, num mundo onde reina a incerteza, a instabilidade real ou latente.

Falar de globalização é evocar a dominação do sistema capitalista sobre o espaço mundial, fenómeno que se inscreve numa tendência de submissão progressiva de todos os espaços físicos e sociais à lei do capital, à lei da acumulação contínua que é a finalidade suprema do sistema capitalista.

Segundo a OCDE, a globalização desenvolveu-se em várias fases, a última das quais, a da globalização, corresponde à instalação de verdadeiras redes planetárias, graças aos progressos da tecnologia e dos serviços. Os Estados tornaram-se cada vez mais interdependentes, prisioneiros do "sistema-mundo".

Com efeito, depressa, o vocábulo "globalização" passou a ser entendido como uma realidade mais ampla e complexa, que vai muito para além da 
dimensão económica, passando a abranger também a ciência e tecnologia, e as relações sociais, políticas e culturais. A globalização assume, deste modo, um significado muito mais amplo, a traduzir as transformaçōes económicas, sociais, culturais e políticas do mundo presente, "a multiplicidade de ligaçôes e interconexôes entre os Estados e as sociedades que caracterizam o sistema mundial ao presente" (Anthony McGraw e Paul Lewis). Assim se compreende que as características da globalização incluam "a internacionalização da produção, a nova divisão internacional do trabalho, nos movimentos migratórios de sul para norte, um novo ambiente competitivo que acelera estes processos e a internacionalização do Estado, transformados em agências do mundo globalizado" (Robert Cox).

Entendida nos países em vias de desenvolvimento, e nos muçulmanos em particular, como uma espécie de neocolonialismo - "globalização é o que nós no Terceiro Mundo, durante séculos, chamamos colonização" (Martin Khor) -, como o domínio do Ocidente sobre o resto do mundo (Anthony Giddens), a globalização não é sinónimo de americanização, nem de homogeneização, quer sob o ponto de vista social, quer sob o ponto económico ou cultural. Torna-se evidente que os Estados Unidos da América são determinantes na globalização económica - o maior mercado de capitais -, militar - é a única potência capaz de intervir em qualquer parte do mundo -, social - é o centro da "cultura popular" - e ambiental - são o país mais poluente do mundo e sem a sua concordância, as decisões em política ambiental obterão sempre resultados limitados. Sendo um dos principais impulsionadores e beneficiários da globalização contemporânea, os Estados Unidos não são capazes, porém, e sê-lo-ão cada vez menos, de a controlar. O Grande Satã dos fundamentalistas islâmicos nem é Satã e menos ainda é grande - a intervenção da Reserva Federal de Nova Iorque, em 1997, para evitar o colapso de um fundo de investimento; as destruições levadas a cabo em 2001 nas cidades de Nova Iorque e Washington; a proliferação da droga e a lavagem de dinheiro no seu território; e recentemente o furacão Katrina, que devastou boa parte do território americano com uma violência, que teve tanto uma inaudita quanto inoperacional resposta da administração americana, revela que os Estados Unidos não estão imunes às crises financeiras mundiais, ao terrorismo internacional, ao narcotráfico e ao aquecimento global do planeta, para o qual contribuem determinantemente, nem estão preparados para dar uma resposta adequada e unilateral a tais fenómenos.

A globalização é americanocêntrica, uma vez que grande parte da revolução da informação e boa parte do conteúdo das redes de informação global são provenientes dos Estados Unidos, aumentando o seu soft power, o poder suave (Nye).

Mas nenhum Estado, incluindo os Estados Unidos, está imune aos efeitos da globalização, a qual, a longo prazo, irá reduzir a intensidade do domínio 
americano. Em suma, nada no mundo pode ser feito sem os Estados Unidos, mas há muito pouco que os Estados Unidos possam fazer sozinhos (Dominique Moisi). A interdependência constitui, efectivamente, uma variável determinante e crescente do mundo globalizado.

A globalização ajudou a reforçar o fundamentalismo, a fortalecer as redes terroristas e, sobretudo, tem contribuído para agravar as desigualdades entre os países ricos e os países pobres e dentro dos próprios países, embora o movimento não seja linear nem geral - a desigualdade dentro dos países, por exemplo, é mais consequência da sua governação e da corrupção que da globalização. Será que a globalização também contribuiu para o alargamento da democracia?

\section{Democracia e globalização}

A democratização, enquanto tarefa complexa - envolvendo aspectos como o respeito pelo Estado de direito e pelas questōes dos direitos humanos, eleições livres reconhecidas internacionalmente, maior descentralização administrativa, acesso à educação e o multipartidarismo -, é empreendida por uma variedade de actores, estaduais e não estaduais, ultrapassando fronteiras nacionais. No contexto da globalização, os processos de construção democrática são afectados por um conjunto variado de factores. Entendida como um processo multifacetado, que envolve forças globais, nacionais, regionais e locais que interagem e se influenciam reciprocamente numa multiplicidade de aspectos - princípios internacionais do direito, know-how das organizações internacionais, interdependência económica global -, a globalização tem consequências visíveis nos processos de construção e consolidação democrática, ora constituindo um factor da sua promoção, ora um elemento de fragmentação.

Os efeitos da globalização têm sido, pois, díspares, ora promovendo valores democrático-liberais, estabilidade e crescente interdependência, ora sugerindo fragmentação, traduzida na recusa de alinhamento com o modelo ocidental de democracia liberal e na preservação de práticas políticas, económicas ou sociais genericamente descritas como não-democráticas. Neste contexto, a relação entre forças globais e nacionais assume particular relevância, demonstrando o modo como os Estados, enquanto entidades singulares no processo global, podem constituir um entrave à difusão e consolidação da democratização. No entanto, apesar de eventualmente poderem optar por uma posição fechada face a estes processos, dificilmente as forças nacionais conseguem alienar-se do processo geral de globalização e do seu impacto e consequências, demonstrando que uma contextualização territorializada de democracia não consegue permanecer imune aos fluxos transnacionais promovidos pela globalização. As sanções da comunidade internacional, no plano económico e político, aos regimes ditatoriais, continuam a ser um importante instrumento de fragilização, erosão e desligitimação dos regimes ditatoriais. 
Para que a globalização seja efectivamente um mecanismo de promoção da democratização, o conceito tradicional de "democracia do povo" tem de ser alargado para além das fronteiras territoriais, no sentido em que, face às forças globais, esta relação não se possa restringir à dualidade população-Estado incluída no entendimento tradicional do termo. Nesta perspectiva, a globalização já teve como efeito a elaboração de políticas supra-estatais, que ultrapassam em larga medida as jurisdições nacionais, demonstrando esta necessidade de abertura a uma compreensão mais ampla.

Para além do Estado nacional, onde é possível a legitimidade democrática no seio da comunidade política, por meio da expressão da vontade popular, a definição de uma comunidade supranacional democrática tem sido complexa. Neste contexto de desnacionalização, as organizações internacionais permitem reflectir decisões políticas restritas no contexto de decisão global, procurando reforçar as comunidades políticas no contexto global. Podem por isso constituir veículos de promoção da democratização, pelo seu papel regulador e de governação a nível supranacional, enquanto respeitando e reflectindo princípios democráticos e de promoção social e económica.

As organizações internacionais têm sido instrumentos fundamentais de estabilidade, por meio de actividades de monitorização, assistência aos processos reformistas e apoio jurídico-legal à democratização. O carácter multidimensional das suas abordagens, incluindo aspectos políticos, jurídicos, económicos, sociais e culturais da vida de um Estado, tem fornecido um enquadramento seguro para o desenvolvimento e para a democratização, por exemplo, na implementação de programas de reforma do sistema judicial ou na adopção de nova legislação de cariz liberal. A sua actuação ao nível, quer da sociedade civil, quer das entidades governativas responsáveis, tem permitido uma abordagem integrada e uma resposta mais eficaz aos desafios da democratização. Além do mais, pelo facto de implicarem a partilha de regras e objectivos comuns, sugerem um nível aprofundado de interacção entre os seus membros, promovendo princípios de cooperação e complementaridade.

Contudo, o sucesso dos processos de democratização num contexto global depende em grande medida do compromisso das autoridades nacionais, bem como do próprio funcionamento das instituições que promovem aqueles. A implementação efectiva de princípios e práticas democráticas não pode ser desvinculada da actividade legislativa e governativa, enquanto definidora das linhas de orientação de qualquer processo de reforma. A não cooperação por parte das entidades nacionais, quer ao nível decisório, quer ao nível da população civil, poderá simplesmente anular o fracasso de qualquer tentativa de enraizamento dos processos democráticos. Por outro lado, o compromisso aparente para com a democratização, na realidade não constituindo objectivo a implementar, poderá servir de cobertura a práticas menos democráticas, de forma a evitar o criticismo da sociedade internacional. 
Além do mais, a própria representatividade e funcionamento das instituições globais nem sempre revela os traços da democracia - constituindo a União Europeia uma das raras instituições internacionais onde existe uma assembleia eleita popularmente. E o que é democracia no seio destes organismos? A igualdade plena dos Estados? Que dizer, da intervenção directa norte-americana no Iraque, com apoio de alguns Estados, sem uma resolução do Conselho de Segurança da Organização das Nações Unidas que a legitimasse? Não será a "exigência” democrática por si só, uma "imposição" pouco democrática? Além do mais, muitas decisões tomadas no contexto das organizações internacionais têm efeitos globais, como, por exemplo, as adoptadas nas reuniōes do G8 ou mesmo da Organização dos Países Produtores e Exportadores de Petróleo (Opep), apesar de apenas um reduzido número de Estados aí ter representação. Não se verifica, por vezes, uma sub-representação ou secundarização de numerosos Estados nas Organizações Internacionais, nomeadamente nas instituiçôes financeiras como o FMI controlado pelos Estados Unidos? E por outro lado, será que países como a Índia, o Japão, a Alemanha e mesmo o Brasil, podem continuar excluídos do Conselho de Segurança das Nações Unidas?

O processo de globalização tem conduzido a uma grande interdependência nas relações internacionais, sendo muitas vezes responsabilizado pela difusão dos princípios liberais e da economia de mercado, a par com os princípios democráticos, donde tem resultado uma adesão crescente às práticas democráticas liberais. Mas se por um lado o processo parece reflectir uma tendência para adesão a princípios de governação mais democráticos e, por isso, mais justos, transparentes, e participativos, por outro lado, tem sido entendido pelos críticos como um processo de hegemonia neo-imperialista liderado pelos Estados Unidos. Estes, atrás de uma cortina democrata-liberal, visariam impor as suas visões e práticas político-económicas, procurando aumentar a sua influência sobre os processos políticos mundiais - o debate entre os defensores das políticas intervencionistas norte-americanas e os críticos da sua hegemonia permanece tão polémico como as discussões sobre as vantagens e desvantagens da globalização.

O final da Guerra Fria e o desmoronamento do bloco do leste são parte deste processo global. Para além das dificuldades e insuficiências inerentes ao próprio funcionamento do regime de Moscovo, a expressão cada vez mais clara de movimentos supranacionais em defesa dos direitos e liberdades fundamentais, por exemplo, constituiu um vector fundamental para a queda do regime soviético e para o início dos processos de transição em muitas das repúblicas da antiga União Soviética, bem como nos Estados da Europa central e do leste, até então na área da sua influência. A Conferência para a Segurança e Cooperação na Europa (CSCE), como instrumento político que ao longo dos anos de Guerra Fria, procurou apaziguar tensões através da promoção de diálogo e acabou por 
dar voz e corpo às aspirações de maiores liberdades e garantias, fazendo também ela parte do processo de transformação que veio a revelar-se unidireccional e culminou com a queda da União Soviética.

Cedo os novos países independentes puseram em marcha processos de transição, voltando-se para o Ocidente como modelo de desenvolvimento a seguir. A realização de eleições livres multipartidárias constituiu um primeiro sinal do esforço de democratização, em alguns casos com numerosos partidos a concurso nos processos de escrutínio. $\mathrm{O}$ respeito pelos direitos humanos e liberdades fundamentais tornou-se também sinal da mudança, juntamente com o fortalecimento da sociedade civil e dos princípios do Estado de direito. Contudo, não sem grandes dificuldades. As mudanças de fundo implícitas nestes processos têm-se revelado difíceis, morosas e exigentes a vários níveis, com expressão no descontentamento generalizado de muitas destas populaçōes, face aos sacrifícios exigidos e ao parco retorno material. E, nalguns países, as redes mafiosas parecem mais fortes que o respeito pelo direito e pelos compromissos democráticos, a revelar a fraqueza do Estado e da sociedade civil.

O regresso de governos comunistas ao poder em vários países do leste demonstrou as dificuldades existentes e o descontentamento das populações, não significando, no entanto, um retrocesso na adesão aos princípios democráticos, que permanecem, de modo geral, como um objectivo a prosseguir. Mas os desafios são muitos, bem como os elementos de oposição e resistência ao avanço dos processos de democratização - o desejo de retenção de privilégios e a ameaça de perda de poder têm-se revelado um forte impedimento à progressão da democratização em alguns países, de que o caso da Bielorrússia constitui um exemplo flagrante.

Por outro lado, o recurso a princípios mais autoritários, sob desígnios democráticos, é prática corrente na Federação Russa, onde o presidente Vladimir Putin tem adoptado medidas bastante restritivas justificadas pela necessidade de garantir a ordem necessária à coroação dos princípios democráticos. Há exemplos reveladores do modo como estruturas centralizadas de um poder autoritário violam os princípios democráticos, sob o pretexto do desenvolvimento económico e da questão da segurança nacional para a manutenção do poder. Interpretações distorcidas de um conceito demasiado amplo.

\section{As dificuldades na tradução dos princípios em acções concretas}

A Teoria da Paz Democrática defende que as democracias consolidadas que partilham regras de actuação e organização não se envolvem em conflito entre si. Com raízes na tradição kantiana, actualizada na versão universal de Fukuyama, os postulados centrais da teoria referem-se à partilha de normas num contexto de competição política e resolução pacífica de diferendos, que 
se estende para além das fronteiras estaduais. Contudo, estas normas não têm evitado o envolvimento de Estados democráticos em guerras de feição neocolonialista ou em conflitos de duvidosa legalidade contra regimes autoritários, para além do seu envolvimento em actividades menos claras entre si, recorrendo por vezes ao uso da acção coerciva de carácter militar ou das sanções económicas. E, muito menos, têm impedido que o processo de democratização nos regimes em mutação ou transição, limite, por si só, os riscos da guerra.

Defendendo a contribuição das organizações internacionais na construção da paz democrática, esta teoria entende a democratização como um instrumento necessário para o alargamento da área de paz e estabilidade a nível global. Uma vez que os governos democráticos são directamente responsáveis perante uma comunidade civil, e as populações, de um modo geral, são adversos ao uso de violência na resolução de conflitos, as democracias são promotoras da paz. Contudo, como Samuel Huntington afirma, "the democratic peace argument is valid as far as it goes, but may not go all that far". Os exemplos da história questionam esta abordagem, com intervenções de carácter colonial e neoimperialista, apoio a regimes não-democráticos e uso de técnicas nãodemocráticas na promoção de interesses nacionais, em particular de carácter económico. Um mundo mais democrático poderá, então, não significar um mundo mais pacífico?

Aqui, a relação entre o Ocidente e o Islão, ou a forma como os países democráticos ocidentais se têm envolvido nos processos de transformação política na África ou na América Latina são relevantes. Diferentes pesos e medidas para situações similares têm gerado reacções de descontentamento e mesmo actos violentos da parte de alguns grupos. Os atentados de 11 de Setembro em Nova Iorque e Washington e a crescente onda de tensão expressa na sucessão de ataques terroristas em várias partes do mundo, demonstra o desprezo contra a imposição do modelo ocidental democrático-liberal, enquanto reflexo de práticas neo-imperialistas de controlo e influência. Podemos então questionar se estas diferentes dimensões do processo de democratização no contexto de globalização demonstram uma tendência para consolidação dos processos ou, ao invés, para uma crescente fragmentação do sistema internacional. A resposta não é simples, uma vez que se pode demonstrar a existência paralela das duas tendências, com as implicações que daí advêm.

Factores de consolidação e fragmentação combinam-se no processo de democratização pós-Guerra Fria, processo este enquadrado na globalização, como força também impulsionadora e simultaneamente limitadora. O desejo de participação nos processos económicos internacionais como factor de progresso e desenvolvimento das economias tem-se revelado como elemento motor de ambos os processos de democratização e globalização. Mas a submissão de valores sociais e culturais a estes mesmos processos tem-se afirmado, por seu turno, difícil, em virtude de uma certa homogeneização e 
absorção de identidades nacionais ou regionais, inaceitáveis para muitos grupos sociais. Os movimentos anti-globalização têm aqui um papel relevante, chamando a atenção para os perigos de uma globalização sem regras. Centrandose na dimensão da igualdade inerente ao conceito de democracia, apelam a uma globalização mais altruísta e solidária, onde os países ricos disponham dos meios necessários à concretização de projectos de desenvolvimento dos países menos favorecidos, de modo a diminuir o fosso entre ricos e pobres. A igualdade social e política constituem os princípios chave subjacentes a estes movimentos, com base nos quais defendem a democratização das relaçóes globais.

As reacçôes ao processo global podem ter reflexo directo na democratização, através da afirmação de poderes autoritários limitadores dos princípios de participação e escolha, característicos da democracia, afirmando-se como regimes contra um processo oculto de imposição de uma forma mundial de governação assente nos princípios democrático-liberais. É o caso, entre outros, dos regimes islâmicos que combatem a ordem mundial promovida pelo Ocidente e liderada pelos Estados Unidos.

A tradição islâmica funde num único sistema, o político, o legal e o espiritual, traduzindo uma visão da vida em comunidade claramente distinta da visão secular dos Estados ocidentais. Nesta amálgama de princípios que estruturam a vida política nos regimes islâmicos, a centralização do poder é uma característica fundamental para a manutenção da lei e ordem. À luz dos princípios democráticos liberais proclamados no Ocidente, podemos caracterizar estes regimes como pouco democráticos. As liberdades políticas e cívicas são muito limitadas e a participação popular extremamente restrita. Num entendimento amplo de democracia, questóes de direitos humanos e de respeito pelas liberdades fundamentais são, também, frágeis. E o papel das mulheres nestas sociedades, elemento incontornável para a compreensão da sua mundividência, revela-se inaceitável.

As vivências políticas, sociais, culturais e económicas dos mundos árabe e ocidental demonstram o seguimento de caminhos distintos, revelados de forma pragmática na estruturação da vida em sociedade em cada um destes mundos. Pontos de partida distintos, com pontos de chegada tão diferentes quanto os regimes por eles abraçados.

A intervenção armada norte-americana no Iraque, em 2003, sem a aprovação prévia de uma resolução nesse sentido, no seio do Conselho de Segurança das Nações Unidas, logo, sem a legitimação internacional, visava o desmantelamento da produção industrial de armamento nuclear no país, vista como ameaça à segurança e estabilidade internacionais. Além do mais, visava o derrube do regime despótico de Saddam Hussein, regime esse que desenvolvia um terrorismo de Estado, e a reposição em seu lugar de um novo governo de orientação democrática, similar, tanto quanto possível, aos governos ocidentais. 
Os líderes árabes eleitos têm reportado a ausência de democracia nos seus países ao enraizamento sociocultural e histórico que envolve as sociedades islâmicas, à interferência estrangeira como motivando ainda mais a afirmação de um poder autoritário, ou à complexidade do Islão plural, nostálgico, por razōes que agora não importa analisar, da charia. Mas talvez a verdadeira razão seja mais simples e se encontre na recusa e receio dos líderes locais face a uma eventual perda de poder.

A democracia não é certamente o modelo último e final, traduzindo o ideal supremo de organização política e social. Mas muitos dos princípios ditos democráticos correspondem ao respeito por valores, liberdades e direitos fundamentais da existência humana. A questão do Ocidente versus mundo islâmico ultrapassa, no entanto, em grande medida, estes aspectos. Desígnios económicos e interesses geoestratégicos de controlo da produção e rotas de distribuição do petróleo, e que pautaram, em parte, a acção de Washington, levantam interrogaçõos sobre intervenção e imposição, bem como de saber-se até onde poderá ou deverá ir o esforço de democratização. Até que ponto este ultrapassa princípios de legitimidade internacional, traduzindo ele mesmo práticas pouco democráticas? Será que o Estado islâmico constitui no mundo político de hoje, "a única alternativa sistémica" à democracia, como pretende Larry Diamond?

Questôes que permanecem em aberto, revelando o debate tradicional entre uma visão mais institucionalista das relaçōes internacionais, que promove a integração de esforços no âmbito de instituições plurais, e uma perspectiva mais realista, onde os interesses nacionais se sobrepõem ao interesse colectivo, como a intervenção americana no Iraque parece evidenciar.

Perante estas ameaças e desafios, democratização e globalização assumemse no contexto actual como processos fundamentais na formulação de uma nova ordem internacional. A questão que neste contexto se impõe é a seguinte: como democratizar a globalização?

\section{Democratizar a globalização?}

Globalização e democratização podem ser entendidos, assim, como processos complementares, revelando cooperação e competição, promovendo avanços em conjunto e retrocessos pelas contradiçóes inerentes à própria conceptualização e interpretação dos termos. Deste modo, os processos democráticos, quer a nível local, nacional ou global, necessitam de acompanhamento constante, pois práticas não-democráticas são recorrentes. Será, assim, possível democratizar a globalização?

Um processo desta ordem teria de abranger um conjunto alargado de aspectos, já que os processos de construção democrática não estão confinados aos limites territoriais de um Estado, ultrapassando fronteiras e desenrolando- 
se num contexto global, ao qual poderão ir buscar apoio, ou pelo contrário, nele encontrar obstáculos.

A democratização da globalização regista, em paralelo, um activo e um passivo que importa abordar.

Não podemos ignorar que a globalização que se fez sentir nas últimas duas décadas foi acompanhada por um extraordinário crescimento (e reforma) de estruturas e organizaçóes institucionalizadas, assim como de redes de mobilização política com o objectivo de vigiar e regular actividades supranacionais e até de "governação mundial".

Sob este aspecto, podemos dizer até que a globalização não se encontra fora de regulação e controle. A prevalência dos direitos humanos sobre a soberania, a demonstrar que esta é cada vez menos garantia da legitimidade dos Estados no Direito Internacional; a internacionalização das questôes da segurança, nomeadamente no que diz respeito à contenção das armas de destruição maciça (nucleares, químicas e bacteriológicas); a regulação cada vez mais apertada dos mercados financeiros globais; os novos movimentos socioambientais em defesa da paz, dos direitos das mulheres, das minorias, etc. -, desafiando a autoridade do Estado, mobilizando grupos de solidariedade e de resistência; eis alguns dos exemplos que podemos aduzir enquanto factores construtivos de um sentido de pertença, de interesses e de consciência comum, de "comunidade global", os quais, longe de anularem a responsabilidade dos Estados em múltiplos aspectos de cariz local ou regional, são a prova de que estes não estão em condições de resolver certos problemas - segurança, ambiente, saúde pública e regulação económica - que necessitam de novos enquadramentos institucionais globais.

Contudo, embora o processo de globalização tenha unificado fisicamente o globo, a verdade é que não engendrou ainda a comunidade mundial, de que a legitimidade de uma governação democrática global depende.

A fragmentação do mundo em nações, regiôes e culturas constitui um entrave à afirmação de uma política democrática global. A "via asiática" da democracia, as "tradições democráticas" indígenas na África, as novas formas de fundamentalismo, os crescentes nacionalismos, as desigualdades globais da mais diversa natureza reforçam as divisões culturais e a fragmentação mundial, favorecendo políticas autoritárias ou ditatoriais, minando as bases de um entendimento comum de democracia enquanto ética global.

Mas as grandes potências também não têm contribuído para a democratização da globalização, quando pretendem reformar a governação global, pensando apenas nos Estados mais poderosos, e não nos mais populosos ou mais representativos de certas regiōes ou civilizações, como se pretende, por exemplo, na reforma das Nações Unidas. Ou quando se eximem às suas obrigaçôes internacionais, afastando-se dos esforços de manutenção de paz das Nações Unidas, reduzindo a ajuda externa aos países não desenvolvidos, retendo 
as contribuições a que são obrigados para a $\mathrm{ONU}$ e outras agências internacionais ou, pura e simplesmente, como fizeram os Estados Unidos, não ratificando tratados ou convenções de alcance global como o Protocolo de Quioto ou o Tribunal Penal Internacional.

A globalização tem-se assumido em muitas circunstâncias como um processo liderado pelos Estados Unidos e respondendo directamente às suas preocupações, desejos e interesses, erigindo a democratização política, os direitos humanos e as reformas económicas como uma exigência à sua assistência. Nesta perspectiva, a globalização não é entendida como um processo democrático. Para que esta situação possa de alguma forma ser contornada, uma participação mais activa dos vários intervenientes neste processo, de forma directa ou indirecta, é desejável.

A existência de Estados imaturos, incompletos ou marginalizados, a resistência dos poderes do passado, ainda não ultrapassados, assim como os crescentes problemas sociais e económicos, decorrentes de uma conjuntura global desfavorável, não têm contribuído para aprofundar esta via. A globalização abre novas perspectivas e oportunidades, mas acarreta também problemas e dificuldades, em particular, desigualdade económica, que têm reforçado os movimentos de contestação a um processo que dizem injusto e ao serviço dos países capitalistas industrializados. Parte do processo mais amplo da globalização, a transição para o modelo democrático e, acima de tudo, a sua implementação efectiva, têm questionado a própria dimensão democrática da mundialização.

A democratização da globalização pode ser reforçada através de vários meios, incluindo consultas directas às populações sobre questóes globais que afectam o seu quotidiano e as suas vivências, procurando desse modo reduzir o deficit democrático da globalização. Um maior envolvimento dos governos locais nos processos globais, como forma de intensificar a voz das populações no contexto da globalização; a exigência de uma maior transparência na governação supranacional através de uma representação popular acrescida na forma de assembleias e da sua efectiva participação nos processos de decisão transnacionais; e a valorização e reconhecimento de uma maior democratização da sociedade civil como factor de promoção de estabilidade e desenvolvimento - eis alguns dos instrumentos que poderão reforçar a democratização da globalização. Da consolidação de um envolvimento mais alargado de actores e estruturas neste processo global poderão, então, resultar maiores benefícios.

Recentrar e recontextualizar os processos globais em curso, estabelecer novas formas de vida pública e novas maneiras de debater os problemas mundiais, gerir os bens comuns da humanidade, enfim, democratizar e civilizar a globalização é e continuará a ser um desafio extraordinário sob o ponto de vista intelectual, institucional e normativo para as comunidades políticas. 


\section{Conclusão}

O processo de construção democrática e a sua extensão a vastas áreas do globo tem sido pautado por avanços e recuos, não se revelando um caminho linear, contínuo e rápido. Envolvendo diferentes dimensões, actores e factores, têm implicações fundamentais a nível estrutural. Por isso, os resultados dos processos de democratização só poderão ser avaliados a longo prazo. Enquanto uma intervenção armada para depor um regime político autoritário pode durar um dia ou ser uma questão de semanas, a consolidação de um regime democrático, em todas as suas dimensões, pode demorar décadas.

Incluindo uma enorme variedade de aspectos que permitem de algum modo a avaliação do nível democrático de uma sociedade, a questão do respeito pelos direitos humanos e liberdades fundamentais, de um modo especial, temse assumido como um elemento evidente da realização democrática. Mas muitos outros aspectos fazem também parte desta valoração, incluindo a realização de eleiçôes multipartidárias livres, a existência de uma sociedade civil, ou uma estrutura organizada e um funcionamento dos meios de comunicação social.

As organizaçōes internacionais, como vimos, têm sido veículos privilegiados de promoção da expansão democrática, através da partilha de princípios, da promoção de relações directas entre Estados e sociedades, e do desenvolvimento e consolidação de instituições democráticas de governo. Princípios que têm estado subjacentes às actividades de grande número de organizaçóes internacionais, nomeadamente, quanto aos esforços da União Europeia de alargamento, com a recente integração de dez novos Estados da Europa do leste, simbolizando, por um lado, os esforços de construção democrática nestes Estados, e por outro lado, a contribuição da organização para a consolidação e desenvolvimento destes mesmos processos de democratização, como realização essencial dos objectivos de política externa da União.

Nos seus esforços de controlo democrático das Forças Armadas e de desenvolvimento de cooperação militar, a Organização do Tratado do Atlântico Norte tem também demonstrado um esforço e contributo para a democratização, enquanto por exemplo a Organização para a Segurança e Cooperação na Europa, através da promoção de direitos humanos, monitorização de processos eleitorais e adopção e adaptação de legislações nacionais aos princípios internacionais, tem também revelado a contribuição possível para a expansão democrática.

E não esqueçamos a exigência explícita da União Europeia, quanto às práticas democráticas e ao respeito pelos direitos humanos, nos novos Estados-membro e nos aderentes, a qual constitui um importante incentivo para a consolidação do processo democrático na Europa de leste e da Turquia ao presente.

Mas se os contributos das instituições e organismos internacionais e transnacionais se têm revelado um factor de integração global, em muitas 
instâncias estes não têm sido capazes de evitar distorções, traduzidas quer em práticas pouco coerentes no âmbito destes próprios organismos, quer nos países de acolhimento das suas acções. Num contexto de globalização, torna-se então evidente o confronto entre forças de integração e fragmentação, que ora impulsionando ora criando entraves ao processo de democratização, têm efeitos profundos no delinear dos contornos democráticos actuais.

Diferentes visões de democracia remetem para diferentes entendimentos do conceito. A evolução democrática tem demonstrando que o ideal democrático tem tido uma tradução prática limitada. A globalização tem certamente aberto novos caminhos e perspectivas, dos quais, o entendimento alargado de democracia poderá ser um dos resultados evidentes. A "bola de neve" da democratização, de que Huntington fala a propósito da década de 1990, continua a rolar. Mas importa perguntar: em que direcção?

Nesta perspectiva, podemos interrogar-nos até que ponto a intervenção ocidental no Iraque veio reforçar ou fragilizar a ideia de democracia no mundo árabe? As retiradas da Síria do Líbano e de Israel da faixa de Gaza, as eleições na Arábia Saudita, Egipto e no próprio Iraque, o estabelecimento do sistema multipartidário em Marrocos, os tímidos passos ensaiados na Tunísia, Argélia, Bahrein e mesmo no Iémen, não constituem sinais prometedores de um novo espírito? Ou, mais do que uma adesão aos princípios de liberdade e democracia, estamos perante uma estratégia de sobrevivência por parte de regimes anacrónicos, caducos e corruptos, face à pressão externa e à agitação interna? $\mathrm{E}$, por outro lado, como interpretar o caos e a violência em que o Iraque continua mergulhado? Ou a chegada ao poder, no Irão, de um radical, a dar novo fôlego aos partidários do fundamentalismo islâmico extremista, quando muitos analistas estavam convencidos de que as forças moderadas, neste país, estavam a ganhar força e influência? Por outras palavras, como disseminar a democracia e os direitos humanos no mundo muçulmano, uma das linhas de rumo da política externa dos EUA, constante do relatório da Estratégia de Segurança Nacional dos Estados Unidos, em 2002?

A abertura do mundo árabe à democracia não está garantida. As bandeiras nacionalistas, anti-americanas e anti-globalização, continuam desfraldadas e intangíveis. Ninguém nos garante que, em eleições livres, de Marrocos à Indonésia, o poder não seja assumido por fundamentalistas radicais que, sob a capa da democracia, irão rejeitar, afinal, os valores e princípios em que a democracia assenta, assim como a globalização, ambas entendidas como instrumentos de dominação do Ocidente. A chave para o reforço do processo democrático do Islão vai passar pelo futuro do Iraque e pela constituição de um Estado palestiniano?

Seja como for, a globalização da democracia, cujos progressos são evidentes no mundo pós-Guerra Fria, revela-se, apesar de tudo, mais vigorosa que a democratização da globalização. Até que ponto a primeira irá acabar por 
influenciar e determinar a segunda? Eis uma interrogação que irá permanecer, durante muito tempo, como uma questão em aberto.

Recebido em $1^{\circ}$ de novembro de 2005 Aprovado em 05 de março de 2006

\section{Referências bibliográficas}

ANDERSON, Peter; WIESSALA, Georg; WILLIAMS, Christopher (eds.). New Europe in Transition. Londres: Continuum, 2000.

ANDERSSON, Andreas. United Nations Intervention by United Democracies? State Commitment to United Nations Interventions: 1991-1999. In: Cooperation and ConflictJournal of the Nordic International Studies Association, vol. 37, n. 4. 2002.

BADIE, Bertrand. O Fim dos Territórios. Ensaio sobre a Desordem Internacional e sobre a Utilidade Social do Respeito. Lisboa: Instituto Piaget, 1996.

BADIE, Bertrand. O Mundo em Viragem. Sociologia da Cena Internacional. Lisboa: Instituto Piaget, 1999.

BADIE, Bertrand. Um Mundo sem Soberania. Os Estados entre o Artificio e a Responsabilidade. Lisboa: Instituto Piaget, 2000.

BAYLIS, John \& SMITH, Steve. The Globalization of World Politics: An Introduction to International Relations. Oxford: Oxford University, 1998.

BRAUD, Philippe. Science Politique: La Démocratie. Paris: Éditions du Seuil, 1997.

CARLSNAES, Walter; RISSE, Thomas \& SIMMONS, Beth. Handbook of International Relations. Londres: Sage, 2002.

COSTA, Darc \& SILVA, Francisco Carlos Teixeira da (org.). Mundo Latino e Mundialização. Rio de Janeiro: FAPERJ, 2004.

DAHL, Robert. Democracia. Lisboa: Actividades Editoriais, 2000.FREIRE, Maria Raquel. Conflict and Security in the Former Soviet Union. Aldershot: Ashgate, 2003.

FREIRE, Maria Raquel (coord.). Desafios da Democratização no Mundo Global; The Challenges to Democratisation in a Global World (edição bilingue). Porto: CEPESE - Centro de Estudos da População, Economia e Sociedade, 2004.

GÓMEZ, José Maria. Politica e Democracia em Tempos de Globalização. Petrópolis: Editora Vozes, 2000.

HELD, David; et al. Global Transformations: Politics, Economics and Culture. Cambridge: Polity Press, 1999.

HELD, David. Democracy and the Global Order. Cambridge: Polity Press, 1997.

HEYWOOD, Andrew. Politics. Londres: MacMillan Press, 1997.

KEGLEY Junior, Charles \& WITTKOPF, Eugene. World Politics: Trend and Transformation. 5. ${ }^{a}$ ed. Nova Iorque: St. Martin's Press, 1995.

LECHNER, Frank J. \& BOLI, John (eds.). The Globalization Reader. Oxford: Blackwell Publishers, 2000. 
NYE, JR., Joseph. O Paradoxo do Poder Americano. Porque é que a Única Superpotência Mundial não pode actuar Isoladamente. Lisboa: Gradiva, 2005.

NYE, JR., Joseph. Compreender os Conflitos Internacionais: uma Introdução à Teoria e à História. Lisboa: Gradiva, 2002.

SARAIVA, José Flávio Sombra (org.). Relações Internacionais. Dois séculos de História. Entre a ordem bipolar e o policentrismo (de 1947 aos nossos dias). Brasília: Instituto Brasileiro de Relações Internacionais, 2001, vol. II.

SCHOLTE, Jan Aart. Globalization: a Critical Introduction. Basingstoke: Palgrave, 2000.

SMOUTS, Marie-Claude (dir.). Les Nouvelles Relations Internationales. Pratiques et Théories. Paris: Presses de Sciences PO, 1998.

SOUSA, Fernando de (dir.). Dicionário de Relaçôes Internacionais. Porto: Edições Afrontamento, 2005.

SOUSA, Fernando de. Portugal, Brasil e a União Europeia. Estudos Estratégicos. Rio de Janeiro: Centros de Estudos Estratégicos da Escola Superior de Guerra, 2002, n. 2.

SOUSA, Fernando de, Portugal, Brasil e União Européia. Mundo Latino e Mundialização. Rio de Janeiro: FAPERJ, 2004.

SOUSA, Fernando de. Portugal e Brasil no Quadro das Relaçōes Uniāo Europeia-Mercosul. Boletim da Academia Internacional da Cultura Portuguesa. Lisboa: Academia Internacional da Cultura Portuguesa, 2002, n. 29.

SOUSA, Fernando de. Portugal e a União Européia. Revista Brasileira de Política Internacional. Brasília: Instituto Brasileiro de Relações Internacionais, ano 43, 2000, n. 2.

TOURAINE, Alain. O que é a Democracia.? Lisboa: Instituto Piaget, 1996.

VALADÃO, Alfredo G.A. O Século XXI será Americano. Lisboa: Instituto Piaget, 1995.

VIOTTI, Paul \& KAUPPI, Mark. International Relations Theory: Realism, Pluralism, Globalism. Nova Iorque: MacMillan Publishing Company, 1993.

Von HIPPEL, Karin. Democracy by Force: United States Military Intervention in the Post-Cold War World. Cambridge: Cambridge University Press, 2002.

\section{Resumo}

Neste artigo se visa analisar os novos desafios à democracia, em um contexto de acentuada globalização, com o fim da Guerra Fria e a ascensão de uma nova ordem mundial. Assim, faz-se necessário uma redefinição da trajetória conceitual tanto da democracia, como da globalização, visto que ambas assumem distintos conceitos e focos nas diferentes épocas e contextos. Busca-se ainda a análise e o questionamento dos processos atuais de profundas alterações do cenário internacional, tais quais o fenômeno da globalização da democracia e a democratização da globalização.

\section{Abstract}

The article intends to analyze the new challenges of democracy, in a context of stressed globalization, with the end of the Cold War and the rise of a new world order. Therefore, a redefinition of the conceptual trajectory of the democracy and also of the globalization 
is necessary, because both take on different concepts and focuses in different times and contexts. Also, we seek an analyzes and a questioning of the recent processes of profound alterations on the international arena, such as the democracy's globalization phenomena and the democratization of globalization.

Palavras-chave: Democracia - Globalização - Multilateralismo - Ordem Mundial Key words: Democracy - Globalization - Multilateralism - International Order 